\title{
EAU-verslag Andrologie
}

\author{
Marij Dinkelman-Smit
}

\section{Introductie}

De EAU guidelines 'Male infertility, male sexual dysfunction en male hypogonadism' zijn ondergebracht onder een nieuw panel dat dit jaar de eerste 'Sexual and Reproductive Health' richtlijn presenteerde: zeer de moeite waard om te bekijken. Hierna volgt een samenvatting 'Andrologie en testiculaire kiemceltumor' uit de EAU20 Virtual.

\section{Testiculaire Sperma Extractie (TESE) bij mannen met het syndroom van Klinefelter}

In 2018 presenteerde een Britse groep sperm retrieval rates van circa $30 \%$ bij (micro-)TESE bij mannen met het klinefelter-syndroom (KS). Zij werden destijds verguisd, met name door Amerikanen, die ook bij KS-patiënten met atrofische testes en frequent hypogonadisme sperm retrieval rates (SRR) van $60 \%$ claimden. Een Italiaanse studie onder 105 mannen met KS die TESE dan wel micro-TESE ondergingen in vijf centra leverde een SRR van $21 \%$ op [1]. Het testosterongehalte was niet geassocieerd met het vinden van zaadcellen. $15 \%$ van de mannen bleek geen hypogonadisme te hebben bij presentatie. Deze bevindingen passen meer bij de praktijk, hoewel de SRR hoger zou kunnen zijn als bij alle mannen micro-TESE was verricht: een betere keuze bij een gemiddeld testisvolume van $3 \mathrm{cc}$

\section{micro-TESE bij mannen met cryptorchisme}

Een Turkse groep onderzocht SRR bij micro-TESE bij 327 mannen met cryptorchisme in de voorgeschiedenis [2]. Maar liefst $16 \%$ had nog een inguïnale testis en onderging nooit orchidopexie. De gemiddelde SRR was 52\%. Orchidopexie < 10 jaar en een testisvolume $>13 \mathrm{ml}$ waren geassocieerd met hogere SRR's. Opvallend was dat er geen diagnostiek naar germ cell neoplasia in situ (GCNIS) werd verricht: terwijl het overall risico op GCNIS bij niet-obstructieve azoöspermie ruim $2 \%$ is en toeneemt bij risico-

dr. M. Dinkelman-Smit $(\bowtie)$

afdeling Urologie, Erasmus MC Rotterdam, Rotterdam, Nederland m.smit.3@erasmusmc.nl factoren als inguïnale testes. Desalniettemin geeft deze studie de praktijk weer, dat TESE ook succesvol is op cryptorche testes.

\section{Effect van testosteron op benigne en maligne prostaatkankercellen}

Het effect van de testosteronconcentratie op BPH en prostaatkanker (PCa) werd in vitro bestudeerd in cellijnen [3] In beide modellen nam celgroei af bij testosteron op castratiewaarden en bij suprafysiologische testosteronspiegels. Testosteron tussen 1,8 en $230 \mathrm{nmol} / 1$ resulteerde in een lineaire afname van celgroei. Hieruit werd geconcludeerd dat zowel maligne als benigne androgeengevoelige cellen niet saturatieafhankelijk reageren op testosteron, maar dat deze reactie bifasisch lijkt te verlopen. Testosteron replacement therapie (TRT) lijkt veilig na behandeling van PCa; het fysiologisch lager worden van testosteron met de leeftijd hangt mogelijk samen met toename van $\mathrm{BPH}$, en TRT in hoge dosering biedt mogelijk experimentele behandelopties voor PCa.

\section{Complicaties na implantatie van een erectieprothese}

De laatste jaren wordt toevoeging van een antifungal aan de antibioticadip voor erectieprothesen en peroperatieve irrigatie gerapporteerd om postoperatieve infecties te verminderen. Onder 468 diabeten die tussen 2003 en 2018 een erectieprothese-implantatie ondergingen in 18 centra was de gemiddelde postoperatieve infectie 3,3\%, explantatie $4 \%$ en revisie $6 \%$ [4]. Een antifungal toevoegen gaf geen betere bescherming. Vancomycine + gentamicine gaf significant minder infectie $(1,4 \%)$ dan een rifampicine + gentamicine-oplossing (5,6\%).

De overall complicaties na een erectieprothese zijn laag [5], waardoor implantatie bij geselecteerde patiënten een uitstekende behandeloptie is voor therapieresistente erectiele disfunctie. Onderdiagnose en -utilisatie van behandeling van seksueel functioneren van de prostaatkankerpatiënt bleken weer uit een Britse studie: seksuele disfunctie bij patiënten die radiotherapie of androgeendeprivatietherapie afrondden, werd niet besproken door $34 \%$ van de ondervraagden [6]. 


\section{De ziekte van Peyronie}

Inflammatie is een belangrijke component van de chronische fase van de ziekte van Peyronie (PD). Waargenomen upregulatie van cytotoxische T-lymfocyten en myofibroblasten biedt mogelijk ingang voor immuuntherapie van PD [7].

Cavernoplicatie en cavernoplastiek blijven vooralsnog de belangrijkste symptomatische behandelopties voor peniscurvatuur, nu collagenase-injecties niet meer beschikbaar zijn. Handige weetjes: cavernoplicatie geeft 3-6 mm lengteverlies per 15 graden curvatuurcorrectie. Uit een serie cavernoplastieken met 60 maanden follow-up bleek wat urologen die grafts doen allang weten: dit is geen procedure voor penisverlenging: bijna $80 \%$ van de patiënten rapporteert penisverkorting en $37 \%$ van de patiënten heeft postoperatief significante erectiele disfunctie (ED) die reageert op behandeling met PDE 5-inhibitors of androskat [8]. Dit als prijs voor een gecorrigeerde stand, dat dan weer wel.

Salamanca presenteerde een overzicht van de behandeling van PD, en benadrukte dat implantatie van een erectieprothese met remodelling van de penis of aanvullende incisie in de corpora cavernosa uitstekende behandelresultaten geeft voor patiënten met PD en pre-existente ED (Plenary session 07 'Testis cancer and surgical andrology').

\section{Erectiele disfunctie}

De kwaliteit van studies naar low intensity shock wave therapie voor ED was weer bedroevend. 18 mannen met milde ED die 18 sessies LiST ondergingen, behaalden dezelfde toename in IIEF-score als bij een PDE 5-remmer; de studie had echter niet genoeg power [9]. We kunnen deze behandeling dus nog steeds als niet-bewezen effectief beschouwen.

\section{Porno kijken}

Veel twitteractiviteit genereerde een Antwerpse cross-sectionele studie onder 3.267 mannen naar hun pornokijkgedrag [10]. De IIEF-score en satisfactie van partnerseks correleerde negatief met porno kijken. Kanttekeningen zijn wel dat de IIEF gebaseerd is op partnerseks en dat ook veel jonge mannen zonder partner meededen aan de studie.

\section{Testiculaire kiemceltumoren en Germ Cell Neoplasia in Situ}

Joost Blok presenteerde zijn werk [11]; mannen met een testicular germ cell tumor (TGCT) hebben een 15 keer hoger risico op een contralaterale TGCT dan mannen in de algemene bevolking. Seminoompatiënten hebben een hoger risico, oudere mannen en status na platinumchemotherapie hebben een lager risico.

Deze bevinding sluit aan bij de boodschap die ik verkondigde in Plenary session 07. Promoot zelfonderzoek van de testes bij mannen met risicofactoren voor TGCT als testiculaire microlithiasis (TM), ga actief op zoek naar de precursorlaesie GCNIS in de contralaterale testis van TGCT-patiënten door twee biopten te nemen van de contralaterale testis bij atrofie $(<12 \mathrm{ml})$, cryptorchisme en TM [12]. Behandel GCNIS om progressie naar TGCT te voorkomen met preventieve orchidectomie, radiotherapie of uitgestelde behandeling als de patiënt eerst vader wil worden. En besef dat chemotherapie niet effectief is voor het behandelen van GCNIS.

Hersham presenteerde een serie radicale orchidectomieën; van de 113 tumoren in vijf jaar bleek maar liefst $23 \%$ benigne [13]. Oudere leeftijd van de patiënt en avasculair echografisch aspect bleken significante voorspellers van benigne laesies. Opvallend was de bevinding van 5,6\% positieve funiculussnijranden bij maligne testistumoren. Gepoolde data uit het Nederlands Kankerinstituut, het Universitair Medisch Centrum Utrecht en de Noordwest Ziekenhuisgroep lieten vergelijkbare resultaten zien: $32 \%$ van de geopereerde testislaesies met normale tumormarkers bleek benigne [14].

Dit geeft maar weer aan hoe belangrijk het is om ziekte in kaart te brengen alvorens over te gaan op radicale orchidectomie. Bij twijfel kan excisie met een vriescoupe in een expertcentrum overwogen worden en bij hoogvolume (gemetastaseerde ziekte) TGCT is uitgestelde orchidectomie, na systemische neoadjuvante behandeling, de beste optie om positieve snijranden te voorkomen.

In London is gestart met een patient centered pathway voor testistumoren, zoals wij dit in Nederland gelukkig al hebben [15]. Hierbij wordt diagnostiek, inclusief CT en een poging tot semencryopreservatie afgerond voordat wordt besloten tot de radicale orchidectomie. Vergelijkbaar met Nederlandse data, melden zij azoöspermie bij $15 \%$ van de patiënten, bij wie vervolgens onco-TESE werd aangeboden. Opvallend is de mediane tijd tussen echo scrotum en orchidectomie van negen dagen in de Britse setting.

\section{Ejaculatiestoornissen}

Kort nog een verslag van ejaculatiestoornissen. Azoöspermie op basis van ejaculatory duct obstruction (EDO) is een zeldzame diagnose. Een systematische review van 29 studies naar TUR van de ejaculatory ducts (TURED) onder 635 mannen resulteerde in zwangerschap in $0-40 \%$ van de gevallen (mediaan 25\%); zoals te verwachten hadden patiënten met partiële EDO en congenitale oorzaak een hogere kans op zwangerschap. Complicaties traden op in $0-36 \%$ van de gevallen (mediaan $10 \%$ ), met als top drie: epididymitis, waterig ejaculaat en hematurie [16]. Alle geincludeerde studies hadden een hoog risico op bias, waren retrospectief en bevatten kleine series. Geen bewijs dus dat TURED een veilige behandeling is van EDO, mijn advies: niet doen.

Retrograde ejaculatie na TURP werd door Laetitia de Kort en Hermans bediscussieerd ('Thematic session 02 Men's Health 2020'). Belangrijke boodschap was dat een positieve ervaring van het orgasme geassocieerd is met antegrade ejaculatie. Informed consent voor ingrepen 
met een hoog risico op retrograde ejaculatie is essentieel en om de kans op antegrade ejaculatie te behouden, kan voor laser, aqua-ablatie, urolift of embolisatie gekozen worden, hoewel deze methoden mogelijk minder effectief zijn voor de behandeling van LUTS en langetermijnuitkomsten niet beschikbaar zijn.

\section{De uroloog als poortwachter}

Tot slot was er weer ruimschoots aandacht voor de uroloog als poortwachter voor de mannelijke gezondheid, voor zowel mannen die zich presenteren met ED als met subfertiliteit. De lezing van Parnham zette alles op een rij voor ED als verklikker van endotheliale disfunctie en voorbode van hart- en vaatziekten, met aandacht voor de associatie tussen OSAS en ED, en vitamine D-deficiëntie en ED (Thematic session 02 'Men's health 2020'). Boeri noemde de subfertiele man een lucky man, omdat een bezoek aan een uroloog in verband met onvervulde kinderwens de kans biedt om de risicofactoren in kaart te brengen en te reduceren die de associatie met kanker (waaronder testiscarcinoom), overall health status en overlijden veroorzaken. Mogelijke verklarende pathofysiologie zijn hypogonadisme, defecten in de DNA repairgenen die zowel infertiliteit als kanker kunnen beïnvloeden als gedeelde leefstijlrisicofactoren. De studies van zijn baas Salonia en epidemiologische studies van Eisenberg waaraan Boeri refereerde, liegen er niet om. Maar in mijn ervaring is een consult vanwege afwijkende semenanalyse aanvullen met risicopreventie voor hart- en vaatziekten, in eerste instantie door middel van leefstijladviezen, uitleg over gecompenseerde testisfunctie (verhoogd LH en FSH) met risico op hypogonadisme op termijn en benoemen van risicofactoren van zaadbalkanker een uitdaging: maar wel een uitdaging waarvan ik hoop dat $\mathrm{u}$ hem ook aangaat!

Open Access This article is distributed under the terms of the Creative Commons Attribution 4.0 International License (http:// creativecommons.org/licenses/by/4.0/), which permits unrestricted use, distribution, and reproduction in any medium, provided you give appropriate credit to the original author(s) and the source, provide a link to the Creative Commons license, and indicate if changes were made.

\section{Bronnen}

1. Boeri L, Capogrosso P, Ventimiglia E, et al. Rate of hypogonadism among Klinefelter patients at first presentation: A multicenter cross-sectional study. EAU20 Virtual, abstract, poster, presentation 421 .

2. Çayan S, Orhan İ, Altay B, et al. Fertility outcomes and predictors for successful sperm retrieval and pregnancy in 327 azoospermic men with a history of cryptorchidism who underwent microdissection testicular sperm extraction. EAU20 Virtual, abstract, poster, presentation 420 .
3. Birch BRP, Hald O. The response of prostate cancer cell lines to exogenous testosterone: Lessons for clinical practice. EAU20 Virtual, abstract, poster 13.

4. Towe M, Osman MM, Huynh LM, et al. Effect of antimicrobial dipping solutions on post-operative infection rates in diabetic patients undergoing primary insertion of a Coloplast titan inflatable penile prosthesis. EAU20 Virtual, abstract, poster 487.

5. Palmisano F, Montanari E, Boeri L, et al. Ten-year experience with prosthetic surgery in the management of erectile dysfunction: Outcomes from a tertiary referral centre and early prosthetic infection predictors. EAU20 Virtual, abstract, poster, presentation 484 .

6. Kinnaird W, Davda D, Mitra AV, et al. The management of sexual dysfunction resulting from radiotherapy and androgen deprivation therapy: A survey of current UK practice. EAU 2020 Virtual, abstract 736.

7. Milenkovic U, Boeckx B, Lambrechts D, et al. Cytotoxic T-lymphocytes and dendritic cells driving the inflammatory micro-environment of Peyronie's disease. EAU20 Virtual, abstract 609.

8. Fiorillo A, Bianchi L, Droghetti M, et al. Is the type of xenograft relevant for patient's satisfaction after surgical treatment of Peyronie's disease? A single-center experience. EAU20 Virtual, abstract, poster, presentation 488.

9. Mykoniatis I, Kalyvianakis D, Kapoteli P, Zilotis F, Fournaraki A, Hatzichristou D. Can low intensity shockwaves therapy compete the efficacy of PDE5is? A pooled data analysis from 2 randomized clinical trials. EAU20 Virtual, abstract, poster 494.

10. Jacobs T, Fog-Poulsen K, Vermandel A, Wood D, de Wachter $\mathrm{S}$, de Win $\mathrm{G}$. The effect of porn watching on erectile function. EAU20 Virtual, abstract, poster, presentation 730.

11. Blok JM, Groot HJ, Huele EH, et al. Incidence of metachronous contralateral testicular germ cell tumour and association with chemotherapy. EAU20 Virtual, abstract, poster, presentation 223.

12. Dinkelman-Smit M. How to manage testicular microlithiasis and CIS. EAU20 Virtual, plenary session 07 - Testis cancer and surgical andrology.

13. Khoo CC, Scott A, Peters M, et al. A contemporary analysis of radical orchidectomy for testis cancer. EAU20 Virtual, abstract, poster, presentation PT370.

14. Bellaar Spruyt JA, Blok JM, Meijer RP, et al. Association between age and histopathology of testicular tumour: Higher risk of benign pathology in older patients? EAU20 Virtual, abstract, poster, presentation PT373.

15. Scott C, Alnajjar H, Alifrangis C, Ahmed Muneer al. Does a patient centric pathway for testicular cancer increase the uptake of cryopreservation, is it feasible and do patients come to harm? A multicentre study. EAU20 Virtual, abstract, poster, presentation PT368.

Dr. Marij Dinkelman-Smit uroloog-androloog, FECSM medisch seksuoloog 